\title{
STAND STRUCTURE OF SHOREAAND SPATIAL DISTRIBUTION OF SHOREA ACUMINATA IN A REHABILITATED AREA OF KENABOI FOREST RESERVE
}

\author{
Fatma NAH ${ }^{1,2, *}$, Wan Juliana WA ${ }^{3,4}$, Shaharuddin $\mathrm{MI}^{5}$ \& Wickneswari $\mathbf{R}^{1}$ \\ ${ }^{1}$ Department of Biological Sciences and Biotechnology, Faculty of Science and Technology, Universiti Kebangsaan Malaysia, \\ 43600 Bangi, Selangor, Malaysia \\ ${ }^{2}$ Centre of Foundation Studies, Universiti Teknologi MARA, Cawangan Selangor, Kampus Dengkil, 43800 Dengkil, \\ Selangor, Malaysia \\ Department of Earth Sciences and Environment, Faculty of Science and Technology, Universiti Kebangsaan Malaysia, \\ 43600 Bangi, Selangor, Malaysia \\ ${ }^{4}$ Institute of Climate Change (IPI), Universiti Kebangsaan Malaysia, 43600 Bangi, Selangor, Malaysia \\ ${ }^{5}$ Institute for Environmental and Development (LESTARI), Universiti Kebangsaan Malaysia, 43600 Bangi, Selangor, \\ Malaysia
}

*fatma@uitm.edu.my

Submitted June 2019, accepted December 2019

\begin{abstract}
The purpose of this study is to determine the stand structure of Shorea species and spatial distribution of Shorea acuminata in a 1-hectare plot within the rehabilitated area of Kenaboi Forest Reserve (FR), Jelebu, Negeri Sembilan. An understanding of the rehabilitation that transpires the area after the plantation of Shorea species will enable us to devise silviculture systems for a better sustainable production as well as conservation of the environmental quality. The diameter at breast height (DBH) and coordinates of 395 trees with $\mathrm{DBH} \geq 5 \mathrm{~cm}$ were recorded in this study. The tree density decreased with the increase in DBH. This observation indicated that the regenerating process of Shorea trees was still active but distracted within the small pole size class. The basal area and biomass of $S$. acuminata were the highest, i.e. $62 \%$ of the total basal area of Shorea trees and $61 \%$ of the total biomass of Shorea trees. These percentages were almost similar to the range of basal area and biomass of a primary forest. The spatial distribution of $S$. acuminata showed a significant aggregated distribution $(\mathrm{p}<0.05)$, however, it showed a random pattern for planted $S$. acuminata trees. The rehabilitated area of Kenaboi FR was actively recovering and the silviculture practices enhanced the rehabilitation process, transforming the area to become more sustainable for production and conservation.
\end{abstract}

Keywords: Regeneration, dipterocarps, taungya system, sustainable, planted trees

\section{INTRODUCTION}

The rehabilitation of forest ecosystems is a vital strategy to tackle climate change, biodiversity loss and desertification, which are the primary current environmental problems (Jonášová et al. 2006, Jong 2009, Thomas et al. 2014). The rehabilitation of logged and poorly degraded forests in Malaysia with artificial regeneration was embarked with forest plantation, starting with rubber (Hevea brasilienssi) plantation in Kuala Kangsar in 1877. Following that, many trials on forest plantation was conducted for Palaquium gutta along with line plantation for Neobalanocarpus heimii (King) in the 1900s (Krisnapillay et al. 2007). However, the planting was discontinued when Commercial Regeneration Felling was introduced in 1918
(Shaharuddin 2011). Between 1929 and 1941, an experimental plantation of dipterocarps was initiated in Forest Research Institute Malaysia (FRIM), with Shorea being one of the main species (Shukri et al. 2008). Most of the fastgrowing hardwoods, especially Shorea, are the most promising plants for dipterocarp plantation in Peninsular Malaysia (Kobayashi 2004, Kettel 2010, Daisuke et al. 2013, Widiyatno et al. 2014).

Dipterocarpaceae is a well-known and essential plant in Malaysia, not only for its valuable timber tree species, but also particularly for containing the genus Shorea. This genus is known as meranti, which is a crucial native species for forest rehabilitation as it is able to influence the 
structure and function of the tropical forest. Most of the lowland forests of Southeast Asia are described as dipterocarp forests (Slik et al. 2003, Brearly et al. 2004, Ghazoul 2016). In recent decades, many of the Shorea species have been threatened by logging and human activities that have critically reduced the number of individuals and populations (Lee et al. 2006, Naito et al. 2008). It is expected that Malaysia will lose about $8.6 \%$ of its forest cover due to the intensification of logging activities, industrialisation and the amplification of agricultural activities to cater for local and global demands (Mustafa et al. 2012). Sist et al. (2003) reported the importance of sustainable management of the remnant dipterocarp population for sustainable use and species conservation. Therefore, narrowing the gap between forest harvesting practices and conservation requirements for dipterocarp forests is of paramount importance to their sustainability.

One of the most promising forest management and silviculture practices that enhanced sustainable production of forest timber species and rehabilitation of degraded forest area is the taungya system. Taungya is a form of agroforestry practice, which originated from Burma for temporary cultivation on hill land (Tani 2000). The main idea is to reduce the cost of rehabilitation of a degraded forest by using farmers who will conduct forest plantation together with cash crops. Farmers will receive benefits from the cash crops, while the managers or foresters will receive free labour services for forest plantation. The main objective of taungya system is to provide an inexpensive means of forest establishment with satisfactory returns to the farmers of the area (Abd Ghani \& Najib 2009). In Malaysia, the taungya system was initiated with short-term cash crops (banana, tapioca, papaya, pineapple, chilli, pumpkin, maize, groundnut, sweet potato, watermelon, yam and ginger) that were planted by the participating farmers at the early years of tree plantation. After six months, the farmers will plant native tree seedlings as per the permit conditions. The tenure ranged between two to three years until the yield is no longer economic. In some cases, the tenure may even exceed four years. The rehabilitated taungya plot was later reverted to the Forestry Department (Shaharuddin et al. 1992). However, the system is no longer practical in Malaysia due to the new economic policies that prefer variety of industries instead of plantations. Besides, the drive to generate higher income with assurance made the cash crop plantation less attractive (Krishnapillay et al. 2007, Abd Ghani \& Najib 2009).

Kenaboi Forest Reserve (FR) is a lowland and hill dipterocarp forest. The rehabilitated area of Kenaboi FR was treated with the taungya system since 1969 (Cheah 1971, Shaharuddin et al. 1992). The area consisted of 250 acres of degraded forest, consisting of very few merchantable trees that were subsequently clear-felled and burnt by taungya farmers. The rehabilitated area of Kenaboi FR mainly consisted of five compartments: 103, 105, 106, 107 and 132. Compartment 107 of taungya plot area, covering 4.45 ha, was rehabilitated with planting stocks from Sungai Menyala FR. The main indigenous species planted were Shorea leprosula (meranti tembaga), $S$. parvifolia (meranti sarang punai) and $S$. acuminata (meranti rambai daun).

According to previous study by Shaharuddin et al. (1992), compartment 107 in Kenaboi FR was successfully rehabilitated with great potential as the best degraded forest rehabilitation, as well as timber production of selected Shorea species. The area exhibited great performance of selected indigenous and exotic species in terms of survival, growth rate, stem quality and volume production. The study considered compartment 107 of Kenaboi FR mainly as a production area and not for protection and conservation. Besides, the findings from a previous study (27 years ago) are obsolete, and the current conditions of Kenaboi FR rehabilitated areas need to be updated for a better understanding, especially in terms of protection and conservation. Furthermore, the rehabilitated area is almost 50 years of age, being one of the oldest taungya plot areas in Malaysia. Therefore, compartment 107 of Kenaboi FR was a perfect study plot to understand the process of rehabilitation that transpired from a degraded forest to a rehabilitated area. The findings can devise a better silviculture system for sustainable production and conservation of the environment.

Considering these attributes, the study aimed to provide a scientific basis for population dynamics of Shorea trees after the practise of taungya System in compartment 107, the rehabilitated area of Kenaboi FR. Therefore, the aim of the study was to determine the stand structure of Shorea species by examining the tree density for every diameter size class, basal area and biomass. The results from the stand 
structures of planted Shorea trees will indicate the regeneration status of planted trees. The output from basal area and biomass of the Shorea trees will show the status of the rehabilitated area that is either recovering successfully or degrading. The second aim of the study was to elucidate the spatial distribution of S. acuminata, which is the most dominant Shorea species in rehabilitated areas. The output from spatial distribution is useful to understand the spatial relationship of the planted and regenerated trees of $S$. acuminata. Information of the stand structures of Shorea and spatial distribution pattern of $S$. acuminata will show comprehensive interaction that will aid in a better interpretation of the Kenaboi FR rehabilitation.

\section{MATERIALS AND METHODS}

\section{Study site}

Kenaboi FR (300-600 m a.s.l) is located in the district of Jelebu, Negeri Sembilan. The district lies between latitude $2^{\circ} 57^{\prime} \mathrm{N}$ and longitude $102^{\circ} 04^{\prime} \mathrm{E}$. The research was conducted in compartment 107, Kenaboi FR. In this study, five study plots, with dimensions of $20 \mathrm{~m} \times 100 \mathrm{~m}$ each and total area of 1-hectare, were used as the sampling area.

\section{Data collection}

An inventory on the abundance of tree species, species identification and diameter measurement of all trees $\geq 5 \mathrm{~cm} \mathrm{DBH}$ was prepared. Tree identification was confirmed by a botanist from the herbarium of Universiti Kebangsaan Malaysia. Identification was directly carried out in the field for individual trees, recognised to a species level. According to silviculture practices, the Shorea population is categorised into four DBH size classes, i.e., $5-15 \mathrm{~cm}$ (small poles), 15-30 cm (poles), 30-45 cm (small tree) and above $45 \mathrm{~cm}$ (big tree). The DBH size classes is based on 'Manual Perhutanan' from the Forestry Department of Peninsular Malaysia (Anon. 2003).

The location of the $S$. acuminata trees was recorded using global positioning system (GPS), and the distance of each S. acuminata tree was measured using a digital rangefinder. Both measurements were used to plot a coordinate of each $S$. acuminata tree in the scattered chart in excel. The data in excel was imported to the $\mathrm{R}$ package spatstat and calculated for the evaluation of spatial distribution patterns (e.g. clustered or random tree distribution) (Baddeley and Turner 2005). The spatial distribution pattern was calculated as: 1) for all 132 trees of S. acuminata, 2) for $20 \%$ of the highest DBH adult trees of 15 S. acuminata trees and 3) for the 17 regenerant trees of $S$. acuminata. The spatial distribution pattern was not conducted for $S$. parvifolia and $S$. leprosula due to insufficient sample size.

\section{Statistical analysis}

Based on Brower et al. (1997), the abundance parameters, such as density, stand structure and basal area, were analysed as below:

$$
\begin{aligned}
\text { Density }(\mathrm{d})= & \text { number of trees }\left(\mathrm{n}_{\mathrm{i}}\right) \\
& \text { per unit area }
\end{aligned}
$$

where, $n_{i}=$ total individual trees calculated for species $i$

$$
\begin{aligned}
\text { Basal area } & =\pi \mathrm{r}^{2} \\
& =\pi \mathrm{DBH}^{2} / 4 \\
& =0.00007854 \times \mathrm{DBH}\left(\mathrm{m}^{2}\right)
\end{aligned}
$$

where $\mathrm{r}=$ radius and $\mathrm{DBH}=$ diameter at breast height.

The aboveground biomass (AGB) and belowground biomass (BGB) were determined using regression equations by Kato et al. (1978) and Niiyama et al. (2010), respectively. The biomass regression equation by Kato et al. (1978) is defined as follows:

$$
\begin{aligned}
& \text { Height }(\mathrm{m})=(122 \times \text { DBH })(2(\mathrm{DBH})+61)^{-1} \\
& \begin{aligned}
\text { AGB }(\text { dry weight })= & \mathrm{W}_{\mathrm{s}}+\mathrm{W}_{\mathrm{b}}+\mathrm{W}_{\mathrm{l}} \text { in kg } \\
= & {\left[\left(\mathrm{W}_{\mathrm{s}}+\mathrm{W}_{\mathrm{b}}+\mathrm{W}_{\mathrm{l}}\right) \mathrm{A}^{-1}\right] } \\
& {\left[1000 \text { in tha }^{-1}\right]^{-1} }
\end{aligned}
\end{aligned}
$$

- $\mathrm{W}_{\mathrm{s}}$ (weight of stem $)=0.313\left(\mathrm{D}^{2} \mathrm{H}\right)^{0.9733}$

- $\mathrm{W}_{\mathrm{b}}$ (weight of branch) $=0.136 \mathrm{~W}_{\mathrm{s}}^{1.070}$

- $\mathrm{W}_{1}$ (weight of leaves $)=(125 \times 0.124$

$$
\left.\mathrm{W}_{\mathrm{s}}^{0.794}\right) /\left(0.124 \mathrm{~W}_{\mathrm{s}}^{0.794}+125\right)
$$

where $\mathrm{D}=$ diameter at the breast height, $\mathrm{H}=$ height and $\mathrm{A}=$ total area of plots.

The following equation for BGB was based on Niiyama et al. (2010): 


$$
\mathrm{W}_{\mathrm{r}}=0.0262 * \mathrm{D}^{2.497}
$$

where $\mathrm{D}$ is the diameter at breast height.

From the equations of AGB and BGB, the total amount of biomass of the study plot was calculated.

\section{Total biomass $\left(\mathrm{t} \mathrm{ha}^{-1}\right)=\mathrm{AGB}+\mathrm{BGB}$}

The spatial distribution of $S$. acuminata in a 1-hectare plot within the rehabilitated area of Kenaboi FR was determined by Ripley's K distance function, which measures the distribution of pairwise distances among the events (Ripley 1976, Rogerson 2001, Bivand et al. 2008). The Ripley's $\mathrm{K}$ function was calculated using the envelope function of the package 'spatstat' (Baddeley and Turner 2005) of the R software (R Team 2014). In addition, a complete spatial randomness (CSR) point process with similar estimated intensity of the study area was simulated (999 replicates) and compared with the empirical values of Ripley's $\mathrm{K}$, to determine whether the empirical function was present inside or not. The K-function or $\mathrm{K}(\mathrm{r})$ measures the distance between individuals within a population and summarises it before representing into a pattern of spatial distribution as regularity (few trees are close to each tree), independence (CSR) and clustering (all trees are close to each other).

\section{RESULTS AND DISCUSSION}

The stand structure of Shorea species in the rehabilitated area of Kenaboi Forest Reserve

From the inventory, 395 trees above $\geq 5 \mathrm{~cm} \mathrm{DBH}$ were found in the 1-hectare plot of compartment 107 in Kenaboi FR. The most common family was Dipterocarpaceae with 193 individual trees derived from three Shorea species, belonging to Shorea acuminata (33\% of total trees), followed by S. parvifolia (20\% of total trees) and S. leprosula (12\% of total trees). The results indicated that the species composition of stands in the rehabilitated area of Kenaboi FR was dominated by Shorea species. The species richness in the rehabilitated area was lower as compared to a 1-hectare coastal lowland forest plot within Teluk Bahang permanent FR (Zakaria et al. 2011). This is because the rehabilitated area of Kenaboi FR was planted with Shorea trees during the taungya system after abandonment following clearlogging (Shaharuddin et al. 1992). Teluk Bahang FR was selectively logged in the early 1930s, where the method of extraction was employing buffalos to drag out the logs from the forest. Mohd-Yunus and Mansor (2002) reported that richness of species does not only depend on the enrichment planting treatment, but also on the methods of log extraction, which determines the growth of remnant tree species, leading to species composition of stands within the selective logged area. Therefore, the damage of Teluk Bahang FR was nowhere near the clear-logged areas of Kenaboi FR, before the forestry department enhanced the method of rehabilitation. Taungya system, with plantation of native species such as Shorea, contributed stands of species composition in the clear-logged area, leading to rehabilitation of Kenaboi FR. The tree density, with diameter class distribution, for all 395 trees and Shorea trees in compartment 107, Kenaboi FR is shown in Figure 1a. This analysis illustrated the structure of a stand in the rehabilitated area of Kenaboi FR.

The distribution of diameter size classes for all trees was described by an inverse J-shaped curve. The stand structure for all the trees decreased with the increase in diameter size class. The small poles $(5-15 \mathrm{~cm} \mathrm{DBH})$ of all trees had the highest tree density ( $30 \%$ of total trees). Following that, the tree density decreased gradually to $26 \%$ for poles $(15-30 \mathrm{~cm} \mathrm{DBH})$. The density of small trees $(30-45 \mathrm{~cm} \mathrm{DBH})$ continued to decrease to $22 \%$, followed by tree density of big trees (45-60 cm DBH), 20\%. The tree density for all trees above $60 \mathrm{~cm} \mathrm{DBH}$ had the lowest tree density of only $3 \%$. The biggest tree is Artocarpus elasticus, with diameter size class of $101 \mathrm{~cm} \mathrm{DBH}$ (Fatma et al. 2016). The same pattern of tree density with diameter size classes was observed in previous studies, with or without selective cutting management, in regenerated forest areas (Okuda et al. 2003, Numata et al. 2006, Kueh et al. 2011, Pamoengkas et al. 2019). Bunyavejchewin et al. (2003) observed the diameter size classes of Vatica cinera at Huai Kha Khaeng Wildlife Sanctuary with the inverse J-shaped curve, indicating a continuously regenerating population. The inverse J-shaped curve, also demonstrated by UKM permanent forest reserve, indicates that the regeneration process is active even in forest logged 40 years ago (Ahmad Fitri et al. 2018). Pamoengkas et al. (2019) concluded that the inverse J-shaped curve shows that the species 
composition of trees in logged-over forest is in a balanced condition, compared to recovering vegetative with silvicultural system, known as selective cutting and line planting system, and the undisturbed forest known as germplasm preservation areas in Central Kalimantan, Indonesia.

Meanwhile, the diameter distribution for Shorea species shown in Figure 1(b) exhibited a normal distribution curve. The tree density for Shorea trees increased with the increase in diameter size class. The small poles $(5-15 \mathrm{~cm}$ DBH size class) of Shorea trees consist of only $15 \%$ of total small poles. The tree density for Shorea continued to increase gradually from poles (15-30 cm DBH size class) to big trees (above $45 \mathrm{~cm} \mathrm{DBH}$ size class), which is from $47 \%$ of total poles to $73 \%$ of total big trees. The biggest Shorea tree in compartment 107, Kenaboi FR, was S. parvifolia with $80 \mathrm{~cm} \mathrm{DBH.}$
The diameter distribution for Shorea species was mostly contributed by S. acuminata, followed by S. parvifolia and S. leprosula; the tree density for S. acuminata was $68 \%$ of Shorea trees, followed by S. parvifolia $(20 \%)$ and S. leprosula $(12 \%)$. The most dominant tree in the rehabilitated area was $S$. acuminata. Therefore, the curve of diameter distribution for S. acuminata was similar to Shorea trees, showing normal distribution. The tree density of $S$. acuminata increased as the diameter size class increased, from $7 \%$ of 119 trees for small poles $(5-15 \mathrm{~cm} \mathrm{DBH})$ to $52 \%$ of 87 trees for poles $(30-45 \mathrm{~cm} \mathrm{DBH})$, and $51 \%$ of 74 trees for big trees. The biggest tree of $S$. acuminata in compartment 107, Kenaboi FR was $60 \mathrm{~cm} \mathrm{DBH}$. The DBH distribution for both $S$. parvifolia and S. leprosula was similar to $S$. acuminata. However, the tree densities of $S$. parvifolia was smaller, and S. leprosula was smallest for each DBH size class, as compared to S. acuminata.

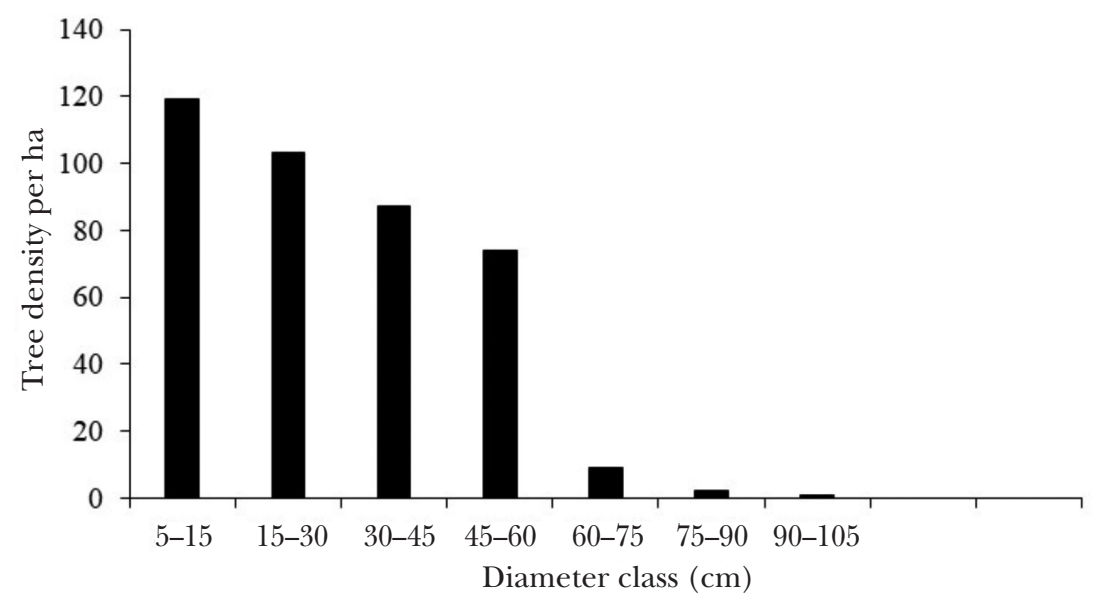

(a)

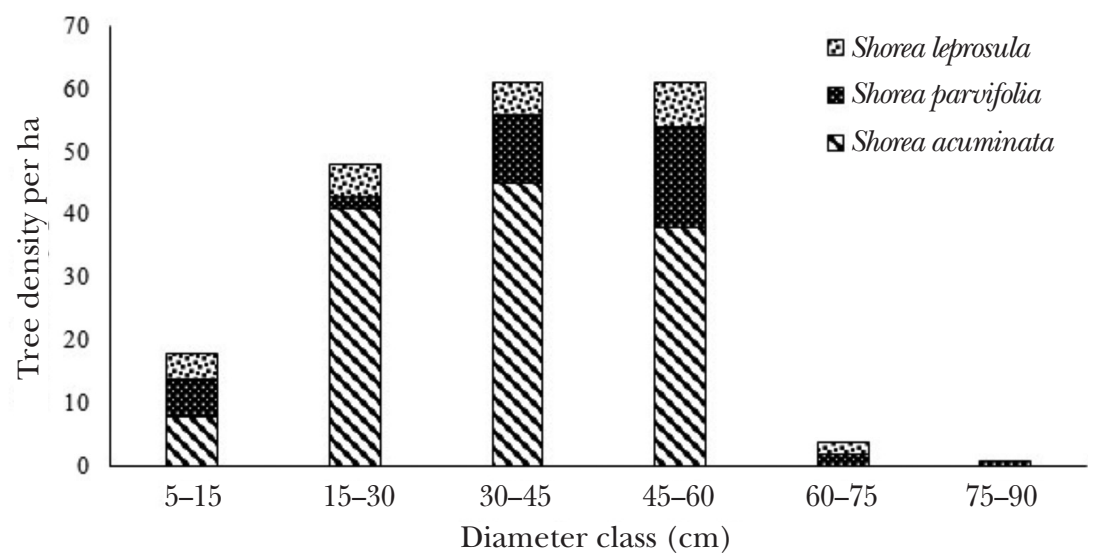

(b)

Figure 1 The diameter distribution of (a) all 395 trees and (b) Shorea species in compartment 107, the rehabilitated area in Kenaboi Forest Reserve 
The rehabilitated area of Kenaboi FR was regenerating. In addition, compartment 107 of Kenaboi FR exhibited many seedlings of Shorea species on the forest floor. However, the study showed that the density of small poles of Shorea trees was the smallest, whereas the density of all high poles was the highest. The silviculturally important plants, the red meranti, including S. acuminata, S. leprosula and S. parvifolia, are characterised by a high demand for light and a rapid early growth (Pamoengkas 2010, Widiyatno et al. 2014, Ghazoul 2016). However, another study showed that the different DBH size classes of Shorea trees have different light acquisition. Extra amount of light can damage the photosynthetic apparatus of dipterocarp seedlings and saplings, therefore, the seedlings and saplings of Shorea species are well adapted to understory shade conditions. Since seedlings and saplings require partial shade from germination to the pole stages, they need increasing amount of light as they approach the canopy (Ghazoul 2016). Different dipterocarp species grow optimally in the gaps of different sizes based on their responses towards light and microclimate (Bebber et al. 2002, Kenzo et al. 2008). In this study, the Shorea seedlings adapted well to shade conditions due to close canopies, and grew rapidly within the rehabilitated area. However, the small poles of Shorea species in compartment 107, Kenaboi FR was likely to receive insufficient light for growth because the high density big trees only allowed light through close canopies. Small poles of Shorea need more light for growth as compared to the seedlings of Shorea trees. Thus small poles of Shorea trees faced high mortality and was unable to survive in compartment 107, Kenaboi FR. This could be the reason why the density of small poles of Shorea was smaller as compared to non- dipterocarp species. About $85 \%$ of the small poles regenerated in the rehabilitated area of Kenaboi FR belonged to non-dipterocarp species.

According to Numata et al. (2006), the difference of light availability on the forest floor between primary forest and regenerating forest is due to the rich stratification of canopy in the primary forest, as compared to the regenerating forest that has lesser stratification of canopy layers. Inada et al. (2017) suggested strip cutting and slashing non-commercial understory species and lianas for increasing the growth of light demanding species such as Shorea. Pamoengkas (2010) recommended some silvicultural treatment, such as liberation, to provide better growing space for dipterocarp species by reducing competition. The early mortality of planted trees in the rehabilitated area of Kenaboi FR is also caused by termites, insect attacks, diseases, fire and prolonged seasonal dryness at rain shadow (Mohd-Ramli \& Ong 1972, Shaharuddin et al. 1992).

Basal area is an important parameter for stand density. In addition, basal area also provides valuable information on the degree of forest stand recovery. The basal area for Shorea species in the rehabilitated area of Kenaboi FR was 23.42 $\mathrm{m}^{2} \mathrm{ha}^{-1}$. The species $S$. acuminata demonstrated highest basal area of $14.58 \mathrm{~m}^{2} \mathrm{ha}^{-1}(42 \%)$, followed by $S$. parvifolia with $5.85 \mathrm{~m}^{2} \mathrm{ha}^{-1}(17 \%)$ (Table 1). Pamoengkas et al. (2018) reported that the basal area of planted forest surpassed primary forest, which are $19.79 \mathrm{~m}^{2} \mathrm{ha}^{-1}$ and $19.64 \mathrm{~m}^{2} \mathrm{ha}^{-1}$, respectively. This is due to the rapid regeneration of non-dipterocarps after selective cutting of forest. However, the rehabilitated area of Kenaboi FR was once a clear-logged are which was planted with stocks of Shorea trees. Gilman et al. (2016) showed similar findings, concluding that the

Table 1 Basal area and biomass of Shorea species in 1-hectare compartment 107, Kenaboi Forest Reserve

\begin{tabular}{lcccc}
\hline Species & Basal area $\left(\mathrm{m}^{2} \mathrm{ha}^{-1}\right)$ & AGB $\left(\mathrm{t} \mathrm{ha}^{-1}\right)$ & BGB $\left(\mathrm{t} \mathrm{ha}^{-1}\right)$ & Total biomass $\left(\mathrm{t} \mathrm{ha}^{-1}\right)$ \\
\hline Shorea acuminata & $14.58(42)$ & 194.75 & 135.70 & $330.45(46.80)$ \\
Shorea parvifolia & $5.85(17)$ & 83.32 & 59.40 & $142.72(20.21)$ \\
Shorea leprosula & $2.99(9)$ & 42.05 & 29.92 & $71.97(10.19)$ \\
Non-dipterocarps & $11.62(32)$ & 144.30 & 103.14 & $160.98(22.80)$ \\
Total & 35.04 & 464.41 & 328.17 & 706.12 \\
\hline
\end{tabular}

AGB is aboveground biomass and BGB is belowground biomass; values provided in parentheses represent the percentage 
factor contributing towards rapid increase in basal area in actively regenerating plots was the use of planted species that enhanced rapid and early growth rates. For example, in Malaysia, the species Shorea is suitable to be planted in the rehabilitated areas of Kenaboi FR for recovery of forest (Krishnapillay 2007, Ghazoul 2016). In addition, this species is also a sustainable timber supply of the forest.

The basal area estimates of S. acuminata was higher as compared to non-dipterocarps, and the highest basal area was displayed at a certain diameter size class, from small to big tree size classes (30 $\mathrm{cm}$ to $80 \mathrm{~cm} \mathrm{DBH)}$ (Figure 2). The highest basal area was also characterised in a plantation forest of Gutianshan National Nature Reserve, Southeast China. This reflected that most of the trees in the plantation belong to the same cohort (Lin et al. 2015). Okuda et al. (2003) obtained a basal area of $34 \mathrm{~m}^{2} \mathrm{ha}^{-1}$ from a regenerating forest, and most of the trees that arose after logging belong to the medium size class. This study concluded that the trees were from the same cohorts after logging activities. Therefore, Shorea trees (30-80 cm DBH) in the rehabilitated area of Kenaboi FR was assumed to belong to the same cohort that consisted of planted Shorea trees taken from Sungai Menyala FR, in the taungya system in 1968. However, the Shorea trees below $30 \mathrm{~cm} \mathrm{DBH}$ might be young trees, subsequently regenerating from the planted Shorea trees. Further studies are needed to assess the paternity analysis of Shorea trees in the rehabilitated area of Kenaboi FR. The information is important for a better understanding of genetic relatedness and quality of the Shorea trees in the rehabilitated area of Kenaboi FR.

The biomass estimate of Shorea species in the study plot was $545.14 \mathrm{t} \mathrm{ha}^{-1}$. The AGB contributed $320.11 \mathrm{t} \mathrm{ha}^{-1}(58.72 \%)$, whereas BGB was $225.03 \mathrm{t} \mathrm{ha}^{-1}(41.28 \%)$. The results indicated that the AGB of Shorea species, in the rehabilitated area of Kenaboi FR, was within the range of Southeast Asia primary rainforest, approximately $300 \mathrm{t} \mathrm{ha}^{-1}$ to $500 \mathrm{tha}^{-1}$ (Laumonier et al. 2010, Niiyama et al. 2010). At the species level, S. acuminata contributed the highest biomass estimate of $330.45 \mathrm{t} \mathrm{ha}^{-1}(46.80 \%)$, whereas AGB and BGB were $194.75 \mathrm{t} \mathrm{ha}^{-1}$ and $135.70 \mathrm{t} \mathrm{ha}^{-1}$, respectively. The second highest biomass estimate was contributed by S. parvifolia of $142.72 \mathrm{t} \mathrm{ha}^{-1}$ or $20.21 \%$ (AGB $=83.32 \mathrm{t} \mathrm{ha}^{-1}$ and BGB $\left.=59.40 \mathrm{t} \mathrm{ha}^{-1}\right)$. The S. leprosula was recorded as the third highest biomass with $71.97 \mathrm{t} \mathrm{ha}^{-1}(10.19 \%)$, whereas both $\mathrm{AGB}$ and $\mathrm{BGB}$ contributed biomass estimates of $42.05 \mathrm{tha}^{-1}$ and $29.92 \mathrm{tha}^{-1}$, respectively (Table 1 ). The AGB of six years stand of $S$. roxburghii in Forest Research Institute Malaysia (FRIM) Research Station in Segamat, Johor was $168.31 \mathrm{t} \mathrm{ha}^{-1}$ (Mun et al. 2018). The total biomass is a very essential parameter that can be used to elucidate productivity and carbon balance assessment of

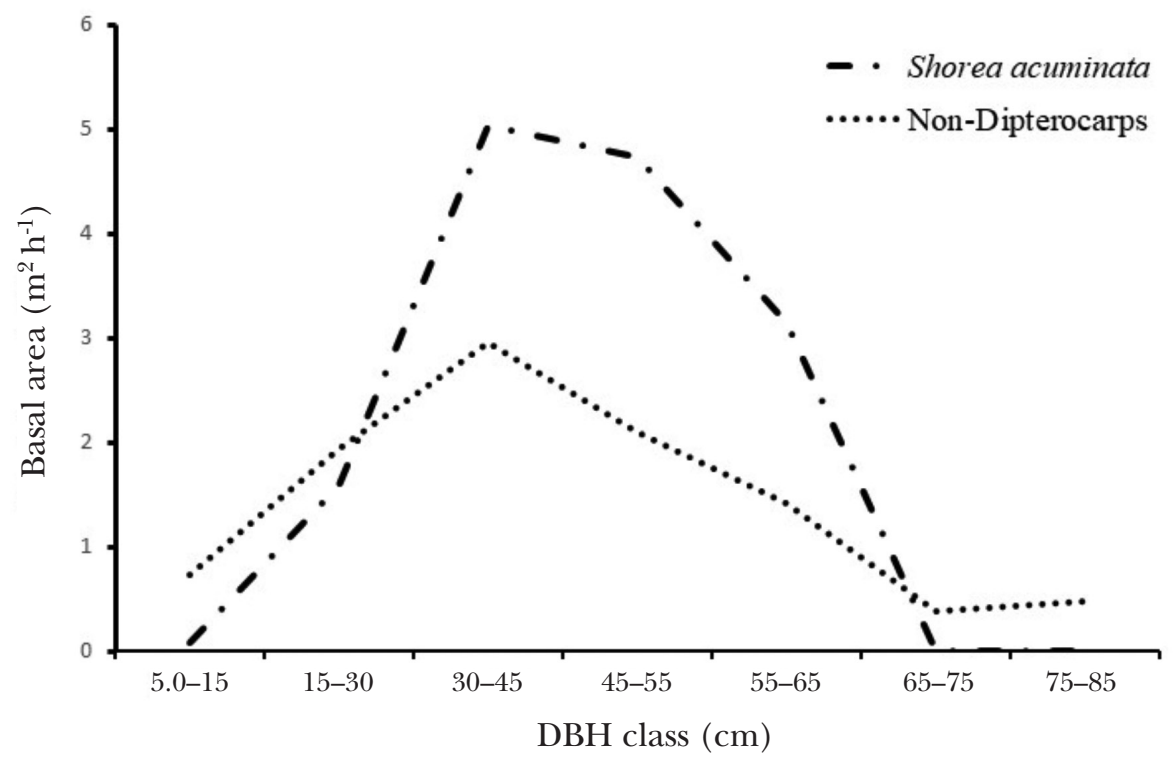

Figure 2 Basal area by the diameter class distribution for Shorea acuminata and non-dipterocarps species in 1-hectare, plot of compartment 107, Kenaboi Forest Reserve 
the forest (Nie et al. 2017). The rehabilitated area of Kenaboi showed an increment of basal area and biomass. A previous study suggests that such increments indicate a notable ability for the rehabilitated area to accumulate and store carbon (Lin et al. 2015).

\section{Spatial distribution of $S$. acuminata in the} rehabilitated area of Kenaboi Forest Reserve

Ripley's K indicated that all 132 individual trees of $S$. acuminata were consistently, significantly and spatially aggregated (Figures $3 \mathrm{a}$ and $3 \mathrm{~b}$ ). The majority of tropical tree species show significant spatial aggregation at various diameter classes (Condit et al. 2000, Seidler $\&$ Plotkin 2006). The possible mechanism of aggregating would be from the aspect of seed dispersal (Seidler \& Plotkin 2006, Smith et al. 2015). The significant spatial aggregation was also found for 17 regenerating trees, which indicates that seed dispersal for $S$. acuminata was short distance, as the seeds were collected within $18 \mathrm{~m}$ from beneath the trunk of each mother tree (Naito et al. 2008). Lee et al. (2016) suggested that the aggregation dispersion is probably due to seed dispersal, gap recruitment, distance-dependent recruitment, as well as topography. However, the spatial distribution pattern for 15 adult trees of $S$. acuminata was significantly and randomly dispersed (Figure 3c). A previous study disclosed that S. acuminata is planted in line planting during the implementation of taungya system. When the system was no longer practised, the rehabilitated areas lacked proper silviculture treatment. Therefore, some of the planted Shorea trees could have died due to inter- or intraspecific competition. Furthermore, the early mortality of planted trees in the rehabilitated areas of Kenaboi FR is also caused by termites, insect attacks, diseases, fire and prolonged seasonal dryness at rain shadow (Mohd Ramli \& Ong 1972, Shaharuddin et al. 1992). As a result, the line planting of Shorea trees showed a random dispersion.

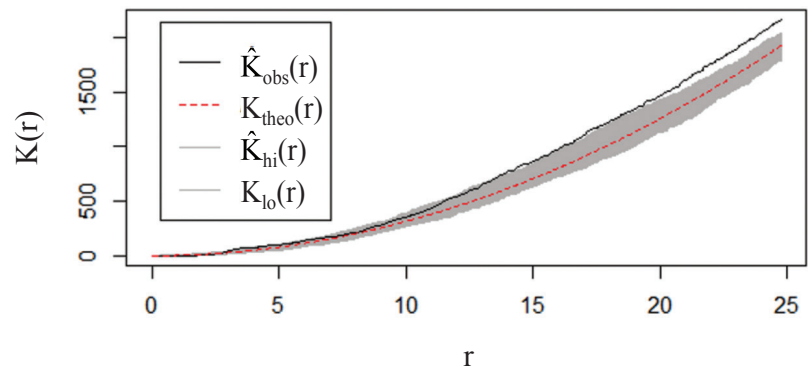

(a)

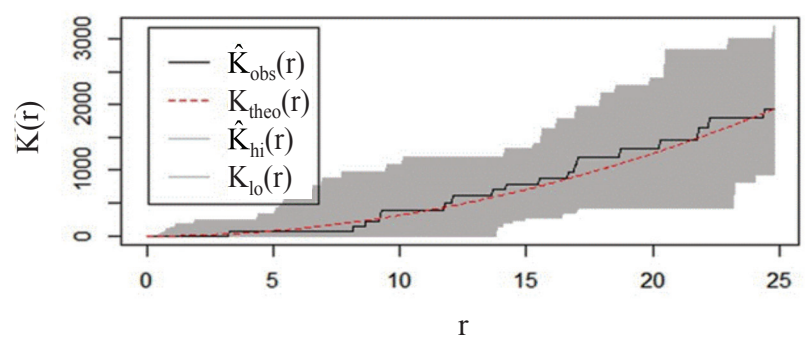

(b)

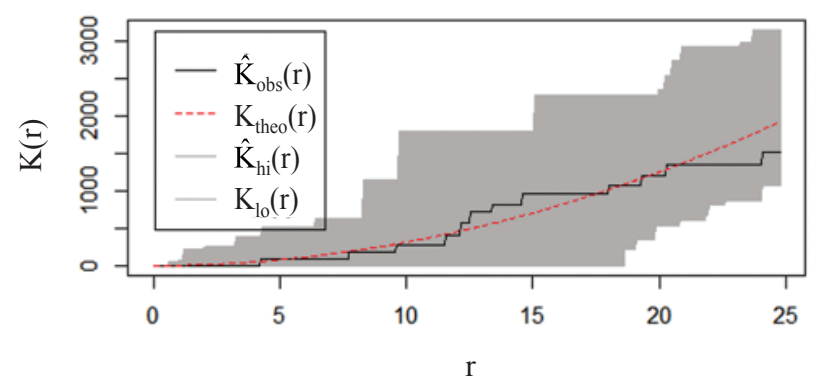

(c)

Figure 3 Ripley's K plots of spatial distribution for (a) all 132 individuals of Shorea acuminata trees (including the planted and regenerated trees of $S$. acuminata), (b) the 17 regenerated trees of $S$. acuminata and (c) the 15 planted trees of S. acuminata in compartment 107, Kenaboi FR; the continuous line $\left({ }_{\text {obs }}\right)$ is the observed function of the individual records, the dashed line $\left(\mathrm{K}_{\text {theo }}\right)$ is the theoretical function of a CSR point process, and the grey shading is the lower and higher limits of the CSR point process after 999 replications; if the observed function is above the CSR limits, then the point process is considered as aggregated, if it is below the limits, then it is considered as regular, and if it is between the limits, it is considered as random 


\section{CONCLUSION}

Compartment 107 of Kenaboi FR was regenerated after clear-logging, which then turned into an abandoned farmland. Later, it was designated into a rehabilitated forest. Unfortunately, the growing process of Shorea trees was distracted within the small pole size class. Silviculture treatment and thinning should be able to enhance light acquisition for better recruitment of small pole Shorea species. The increment of basal area and total biomass of S. acuminata showed that the rehabilitated area of Kenaboi FR was in a recovery process, and at the same time able to efficiently accumulate carbon. The spatial distribution of $S$. acuminata trees was almost similar to the majority tropical trees of the primary forest, which was significantly aggregate. However, planted $S$. acuminata trees indicated a significantly random distribution, even though the trees were systematically planted using line planting during the taungya system. This might be due to inter- and intraspecific competition and early mortality of the planted $S$. acuminata trees. The planting stocks of Shorea species can be used to rehabilitate a poorly degraded forest area. Together with the enforcement of silviculture practices, the rehabilitated area can serve as a sustainable production area, as well as conserve the environmental quality of natural forest.

\section{ACKNOWLEDGEMENTS}

The authors would like to thank the Fundamental Research Grant Scheme for Research Acculturation of Early Career Researchers (RACER), funded by Ministry of High Education of Malaysia with Grant no. RACER/1/2019/ STG03/UITM//2, for financing the research. The authors would also like to thank the School of Environment and Natural Resource Science, Faculty of Science and Technology, Universiti Kebangsaan Malaysia for providing logistics, laboratory space, research staff and assistance during field sampling. Lastly, the authors would like to thank the Negeri Sembilan State Forestry Department for granting permission to conduct research within the forest reserve areas.

\section{REFERENCES}

Abd GHani AR \& Najib LA. 2009. Agroforestry approach of planting timber and non-timber species in Malaysia. Pp 125-135 in Gotoh T \& Yakota Y (eds) Development of Agroforestry Technology for the Rehabilitation of Tropical Forests, JIRCAS Working Paper No 60. Japan International Research Centre for Agricultural Sciences (JIRCAS), Tsukuba.

Ahmad-Fitri Z, Mohd-Azman K, Wan-Norilani et al. 2018. Species composition, community structure and biomass estimation of Anacardiaceae. Pp 34-43 in Kader-Maideen HM et al. (eds) A Natural Heritage: The Flora and Fauna of Universiti Kebangsaan Malaysia. Universiti Kebangsaan Malaysia, Bangi.

Anon. 2003. Manual Perhutanan Jilid 3. Jabatan Perhutanan Semenanjung Malaysia, Kuala Lumpur.

Baddeley A \& Turner R. 2005. Spatstat: an R package for analyzing spatial point patterns. Journal of Statistical Software 12: 1-42. doi: 10.18637/jss.v012.i06.

Bebber D, Brown N, Speight M et AL. 2002. Spatial structure of light and dipterocarp seedling growth in a tropical secondary forest. Forest Ecology and Management 157: 65-75. doi: 10.1016/S0378-1127(00)00659-9.

Bivand RS, Pebesma EJ \& Gòmez-Rubio V. 2008. Applied Spatial Data Analysis with R. Springer, New York. doi: 10.1007/978-1-4614-7618-4.

BlANFORD HR. 1958. Highlights of one hundred years of forestry in Burma. Empire Forestry Review 37: 33-42. https://www.jstor.org/stable/42600438.

Brearley FQ, Prajadinata S, Kidd PS et al. 2004. Structure and floristics of an old secondary rain forest in Central Kalimantan, Indonesia, and a comparison with adjacent primary forest. Forest Ecology and Management 195: 385-397. doi: 10.1016/j. foreco.2004.02.048.

Brower JE, Jerold HZ \& Van Ende C. 1997. Field and Laboratory Methods for General Ecology. Fourth edition. Mc-Hill Companies Inc., New York.

Bunyavejchewin S, Lafrankie JV, Baker PJ et al. 2003. Spatial distribution patterns of the dominant canopy dipterocarp species in a seasonal dry evergreen forest in Western Thailand. Forest Ecology and Management 175: 87-101. https://doi.org/10.1016/S03781127(02)00126-3.

CHEAH LC. 1971. A note on taungya in Negeri Sembilan with particulars reference to the incidence of damage by oviposition of insects in plantation in Kenaboi Forest Reserve. The Malayan Forester 34: 133-153.

Condit R. 2000. Spatial patterns in the distribution of tropical tree species. Science 288: 1414-1418. doi: 10.1126/science.288.5470.1414.

Daisuke H, Kenzo T, Kendawang JJ et al. 2013. Rehabilitation of degraded tropical rainforest using dipterocarp trees in Sarawak, Malaysia. International of Forestry Research: 683017. http://dx.doi.org/10.1155/2013/683017.

Fatma NAH, Wan Juliana WA, Shaharudin Mi \& Wickneswari R. 2016. Community stand structure of rehabilitated forest at Kenaboi Forest Reserve, Negeri Sembilan, Malaysia. Pp 1-7 in Che-Radziah CMZ et al. (eds) Proceedings of The 2016 UKM FST Postgraduate Colloquium. 13-14 April 2016, Bangi. doi: 10.1063/1.4966851.

Ghazoul J. 2016. Dipterocarp Biology, Ecology and Conservation. Oxford University Press, Oxford.

Gilman AC, Susan GL, Rita MF et al. 2016. Recovery of floristic diversity and basal area in natural forest 
regeneration and planted plots in a Costa Rican wet forest. Biotropica 48: 798-808 2016. doi: 10.1111/ btp. 12361.

Inada T, Widiyatno, Hardiwitono S ET AL. 2017. Dynamics of forest regeneration following logging management in a Bornean lowland dipterocarp forest. Journal of Tropical Forest Science 29: 185-197. https:/ / www.jstor. org/stable/44160936.

JoNG WD. 2009. Forest rehabilitation and its implication for forest transition theory. Biotropica 42: 3-9. https:// doi.org/10.1111/j.1744-7429.2009.00568.x.

Jonášová M, Hees AV \& Prach K. 2006. Rehabilitation of monotonous exotic coniferous plantations: a case study of spontaneous establishment of different tree species. Ecological Engineering 28: 141-148. doi: 10.1016/j.ecoleng.2006.05.008.

KATO R, TADAKI Y \& OGAWA H. 1978. Plant biomass and growth increment studies in Pasoh Forest. Malayan Nature Journal 30: 211-224.

Kenzo T, Yoneda R, Matsumoto Y et al. 2008. Leaf photosynthetic and growth responses on four tropical tree species to different light conditions in degraded tropical secondary forest, Peninsular Malaysia. JARQJapan Agricultural Research Quarterly 42: 299-306. doi: 10.6090/jarq.42.299.

Kettle JC. 2010. Ecological considerations for using dipterocarps for restoration of lowland rainforest in Southeast Asia. Biodiversity and Conservation 19: 1137-1151. doi: 0.1007/s10531-009-9772-6.

KOBAYASHI S. 2004. Landscape rehabilitation of degraded tropical forest ecosystems case study of the CIFOR/ Japan project in Indonesia and Peru. Forest Ecology and Management 201: 13-22. https://doi.org/10.1016/j. foreco.2004.06.009.

Krishnapillay DB, RaZak MAA \& Appanah S. 2007. Forest rehabilitation - the Malaysian experience. Pp 85-123 in Don KL (ed) Proceeding of Keep Asia Green. Volume 1. 17-18 February 2007, Bangkok.

Kueh JHR, Abd. Majid NM, Gandaseca S et al. 2011. Forest structure assessment of a rehabilitated forest. American Journal of Agricultural and Biological Sciences 6: 256-260.

Laumonier Y, Edin A, Kanninen M et al. 2010. Landscapescale variation in the structure and biomass of the hill dipterocarp forest of Sumatra: implications for carbon stock assessments. Forest Ecology and Management 259: 505-513. https://doi.org/10.1016/j. foreco.2009.11.007.

Lee SL, NG KKS, SAw LG ET AL. 2006. Linking the gaps between conservation research and conservation management of rare dipterocarps: a case study of Shorea lumutensis. Biological Conservation 131: 72-92. ttps://doi.org/10.1016/j.biocon.2006.02.005.

LEE SL, NG KKS, NG CH ET AL. 2016. Spatial studies of Shorea parvifolia spp. parvifolia (Dipterocarpaceae) in a lowland and hill dipterocarp forest. Journal of Tropical Forest Science 28: 309-317.

Lin D, LAI J, Yang B et aL. 2015. Forest biomass recovery after different anthropogenic disturbance: relative importance of changes in stand structure and wood density. Europian Journal of Forest Research 134: 769-780. doi: 10.1007/s10342-015-0888-9.
Mohd-Ramli M \& ONG KB. 1972 Taungya in Negeri Sembilan. The Malayan Forester 35: 309-316.

Mohd-Yunus Z. \& MAnsor MY. 2002. Teluk Bahang Forest Trail: An Oldest Tropical Rainforest in the Vicinity of the City Penang Malaysia. Penang Forestry Department, Penang.

Mun HW, Faridah AA, Amir SK \& Ang LH. 2018. Assessment of growth and biomass of Shorea Roxburghii G. Don in selected areas of Peninsular Malaysia. International Journal of Agriculture, Forestry and Plantation 7: 46-52.

Mustafa MFJ, Suratman MN \& Isa NNM. 2012. Dipterocarpaceae: survival amidst degradation: a brief compilation for conservation prescription. Pp 158-162 in Zuhabri I \& Mustafar KH (eds.) IEEE Symposium on Business, Engineering and Industrial Application (ISBEIA). 23-26 September 2012, Bandung. doi: 0.1109/ISBEIA.2012.6422858

Naito Y, KanZaki M, Iwata H et al. 2008. Density-dependent selfing and its effects on seed performance in a tropical canopy tree species, Shorea acuminata (Dipterocarpaceae). Forest Ecology and Management 256: 375-383. https://doi.org/10.1016/j. foreco.2008.04.031.

Nityama K, Kajimoto T, Matsuura Y et al. 2010. Estimation of root biomass based on excavation of individual root systems in a primary dipterocarp forest in Pasoh Forest Reserve, Peninsular Malaysia. Journal of Tropical Ecology 26: 271-284. doi: 10.1017/ S0266467410000040.

NiE S, WANG C, ZENG H ET AL. 2017. Above-ground biomass estimation using airborne discrete-return and full-waveform LiDAR data in a coniferous forest. Ecological Indicators 78: 221-228. https://doi. org/10.1016/j.ecolind.2017.02.045.

Numata S, Yasuda M, Okuda T et al. 2006. Canopy gap dynamics of two different forest stands in a Malaysian lowland rain forest. Journal of Tropical Forest Science 18: 109-116.

Okuda T, Suzuki M, Adachi N et al. 2003. Effect of selective on canopy and stand structure and tree species composition in lowland dipterocarp forest in Peninsular Malaysia. Forest Ecology and Management 175: 297-320. https://doi.org/10.1016/S03781127(02)00137-8.

Pamoengkas P. 2010. Potentialities of line planting technique in rehabilitation of logged over area referred to species diversity, growth and soil quality. Biodiversitas 11: 34-39. doi: 10.13057/biodiv/d110108.

Pamoengkas P, Siregar IZ \& Dwisutono AN. 2018. Stand structure and species composition of merbau in logged-over forest in Papua, Indonesia. Biodiversitas 19: 163-171. doi: 10.13057/biodiv/d190123.

Pamoengkas P, Zamzam A \& Dwisutono AN. 2019. Vegetation recovery of logged-over dipterocarp forests in Central Kalimantan, Indonesia. Floresta e Ambiente 26: e20171239. http://dx.doi.org/10.1590/21798087.123917 .

Ripley B. 1976. The Second-Order Analysis of Stationary Point Process. Journal of Applied Probability. 13: 255-266.

R CORE TEAM. 2014. R: A Language and Environment for Statistical Computing. R Foundation for Statistical Computing, Vienna. http:/ /www.R-project.org/. 
Rogerson P. 2001. Statistical Methods for Geography. Sage Publications, London.

Seidler TG \& Plotkin JB. 2006. Seed dispersal and spatial pattern in tropical trees. PLoS Biology 4: e344. https:/ / doi.org/10.1371/journal.pbio.0040344.

Shaharuddin MI, Mohd Basri H \& Samsudin S. 1992. An evaluation of a 19-year old taungya planting in Negeri Sembilan Darul Khusus. The Malaysian Forester 55: $1-12$.

SHAHARUdDin MI. 2011. Forest management systems in Southeast Asia. Pp 1-20 in Wickneswari R \& Cannon C (eds) Managing the future of Southeast Asia's Valuable Tropical Rainforests. A Practitioner's Guide To Forest Genetics. Springer Heidelberg, New York, Dordrecht, London.

Shukri WA, Shamsudin I, Samsudin M et al. 2008. Concept of enrichment planting in tropical forest. Pp 9-28 in Chan HT et al. (eds) An In-Depth Look At Enrichment Planting. Malayan Forest Record No. 47. Forest Research Institute Malaysia, Kepong.

Sist P, Fimbel R, Sheil D et AL. 2003. Towards sustainable management of mixed dipterocarp forests of Southeast Asia: moving beyond minimum diameter cutting limits. Environmental Conservation 30: 364-374. ttps:// doi.org/10.1017/S0376892903000389.
Slik JWF, Poulsen AD, Ashton PS et Al. 2003. A floristic analysis of the lowland dipterocarp forests of Borneo. Journal of Biogeography 30: 1517-1531. https://doi. org/10.1046/j.1365-2699.2003.00967.x.

Smith JR, Bagchi R, Ellens J et al. 2015. Predicting dispersal of auto-gyrating fruit in tropical trees: a case study from the Dipterocarpaceae. Ecology and Evolution 5: 1794-1801. doi: 10.1002/ece3.1469.

TANI Y. 2000. Ecological factors affecting taungya farmers behavior in teak plantation projects: a case study in Bago range, Union of Myanmar. Tropics 10: 273-286. https://doi.org/10.3759/tropics.10.273.

Thomas E, Jalonen R, Loo J et al. 2014. Genetic considerations in ecosystem restoration using native tree species. Forest Ecology and Management 333: 66-75. https://doi.org/10.1016/j.foreco.2014.07.015.

Widiyatno, Soekotjo, Naiem M et AL. 2014. Early performance of 23 dipterocarp species planted in logged-over rainforest. Journal of Tropical Forest Science 26: 256-266.

Zakaria R, Mansor A \& Mansor M. 2011. Tree diversity of a lowland coastal forest, teluk bahang permanent forest reserve, Pulau Pinang, Malaysia. Malayan Nature Journal 63: 601-612. 